tradition, has been left chiefly to the energy of private enterprise. King's College will, without question, be one of the great teaching centres of the new London University. It requires at this moment, to enable it to carry out that great function, the assistance of the public to supply it with adequate scientific accommodation, especially, I am informed, in the matter of bacteriological and physiological laboratories and lecture-rooms; and it may be a matter of some consolation to those who take little interest in scientific matters, unless they can see their immediate application, that both bacteriology and physiology have a most immediate and direct bearing upon the life and happiness of mankind. .In both branches of study King's College has proved itself rich in teachers of eminence. I am not going to discuss - it would be almost impertinent of me even to touch upon-the enormous interests bound up with the successful prosecution of these two great hranches of research; but I may, perhaps, remind you of the enormous practical importance to us, of all people in the world, of some of the more recent researches in bacteriology. Bacteria are a very humble class of organisms, very unjustly abused, as far as I can discover, by ordinary public opinion, in which they suffer, as other classes suffer, by having among them a certain number of black sheep ; but for the most part they are not only innocent, but most useful allies to industry, and almost necessary co-operators in some of those great functions which have to be discharged if the health of great cities is to be maintained. But, apart from that, no doubt our chief interest in them lies in the pathogenic members of the group, and we, of all people in the world, are especially interested in treating of those forms of tropical disease which they have produced, since we are engaged in maintaining a number of our population in countries where the diseases born of these bacteria are the greatest scourges. It is, perhaps, to a distinguished professor of King's College more than to any other man in this country that we owe some of the most useful discoveries in these matters. As the last speaker called attention to Mr. Chamberlain's great work in drawing together the bonds of Empire and knitting in closer unity the various elements that make up that Empire, so I may be permitted, in the wholly different subject with which I have to deal to-night, to remind you that he, as Secretary of the Colonies, has done his best to encourage these bacteriological investigations of which I, at all events, entertain such great hopes that science will soon be able to combat, by its discoveries, the inherent difficulties which have hitherto so greatly militated against Europeans in the tropical climates of the world.

WHAT LONDON SHOULD DO.

I do not know that it is necessary for me at greater length to impress upon you the theme which has been committed to my charge ; but I confess I cannot conclude without admitting that I think this great city has been somewhat remiss in the support which it has hitherto given to scientific investigation in the comnercial metropolis of the world. Technical education, if I may revert for an instant to that subject, has in it almost necessarily some element of competition. We hear it said Germany is doing this, France is doing that, some other country is doing the other, unless you keep abreast of them in your methods of education you will fall behind them in your industrial enterprises. That is a very proper argument; it is a very patriotic argument; it is an argument I myself have used before and shall use again ; it is an argument I should think myself justified in using; but I am appealing to you on behalf of a case which has in it none of this element, this inferior and lower element, of competition whatever. Every scientific discovery, whereso. ever it be made, be it made in Berlin, Paris, London, New York, Vienna, as soon as it is made is the common property of every man of science. Nations may erect against each other some barrier of tariffs, they may engage in some absurd rivalry animated by I know not what sort of suicidal policy ; but men of science wherever they live, to whatever nation they belong, have a cause common to humanity at large, which knows no provincial boundaries, which is not interfered with by any sectional rivalries. To that great common fund of knowledge, the basis after all of your civilisation as it is, the basis after all of the industrial progress you propose to make, I think London should contribute its full share. London takes a well-earned tribute from every discovery made throughout the world for the advancement of civilisation; from all these some section of London gets the benefit. Let those who are dwellers in London feel that they have some obligation to the world at large corNO. I 582 , VOL 6 I] responding to the great, the international position we occupy. Let us do what we can as a community to further that investigation into the secrets of nature, that storming of the citadels of natural knowledge in which all civilised men are, and ought to be, co-operators. Let it not be that, while there are great centres of scientific teaching in every other great metropolis, we have allowed ours for one moment to fall behind in the race.

\section{GENERAL A. A. TILLO}

GENERAL A. A. TILLO, Vice-President of the Russian Geographical Society, who died at St. Petersburg on January II, was the founder of an exact physical geography of Russia, based on correct scientific data. He was born in 1839 , and received his education in the Constantine Military School, from which he was promoted officer in 1859 . He completed next his education by passing through two military academies, artillery and General Staff, and worked for two years at Pulkova in the Geodetic Department of this last academy. In the years $1879-82$, in his capacity as educator of one of the Russian Grand-Dukes, he followed lectures on mathematics in different West European universities, as also a full course of Law at the University of Strasburg. He began geographical work as the head of the surveys of the Orenburg region, by publishing a catalogue of latitudes and longitudes determined in that region, followed by a study of the distribution of magnetical elements, and by a description of the levelling made between the Caspian Sea and Lake Aral. His next works were "On the Byelgorod Magnetic Anomaly," "On the Present Condition of the Science of Terrestrial Magnetism," and "On the Yearly Amplitudes of Variations of Level in the Lakes of Russia," "On the Average Altitudes of the Continents in Both Hemispheres." Settling some fiveand-twenty years ago at St. Petersburg, he began to work out in a most systematic way the different portions of a general physical geography of Russia. The surfaces of different parts of the empire having already been calculated by Strelbitzky, General Tillo measured first, with a very great accuracy, the lengths of the rivers of the Russian Empire, their gradients, and the surfaces of their basins, thus correcting many erroneous statements of his predecessors. Then, he worked for years in collecting all documents relative to the altitudes of European Russia, and finally published in I 889 his most remarkable hypsometric map of European Russia, on a scale of 40 miles to an inch, followed seven years later by the same improved map on a still larger scale ( 27 miles to an inch), in four sheets. This map, by showing the existence of three great depressions amidst the swelling of Middle Russia, completely altered the hitherto current conceptions as to the orography of European Russia. His next work was a most elaborate atlas of isobars in Russia and Asia altogether, and it was followed by still more elaborate works on the distribution of magnetic elements on the surface of the earth, "Variation sécuIaire et éphémérides du Magnétisme terrestre," "Loi de la Distribution du Magnétisme moyen à la Surface du Globe," "Atlas des Isanomales et des Variations séculaires," and "Tables fondamentales du Magnétisme terrestre,"- which won for Tillo a wide European reputation. His smaller contributions to the publications of the Russian Geographical Society were countless. He was a nember of both the St. Petersburg and the Paris Academies of Sciences. His extreme modesty and willingness to undertake any amount of calculations to work out the results of observations made by explorers in Asia, made of him one of the most sympathetic figures in the Russian Geographical Society, in which he presided over the Physical Geography Section. A pamphlet containing an obituary notice of General Tillo, and a full list of his works, has just been published by this Society. 